\title{
Skin structure in the snout of the Australian lungfish, Neoceratodus forsteri (Osteichthyes: Dipnoi)
}

\author{
Q1 A. Kemp** \\ Q2 Griffith School of Environment and the School of Biomolecular and Physical Sciences, Griffith University, 170 Kessels Road, Nathan, Brisbane, Queensland \\ 4111, Australia
}

\section{A R T I C L E I N F O}

\section{Article history:}

Received 28 March 2014

Received in revised form 18 July 2014

Accepted 18 July 2014

Available online $\mathrm{xxx}$

\section{Keywords:}

Lungfish

Lymphatic vessels

Skin sense organs

Tubules

Dermal papillae

\begin{abstract}
A B S T R A C T
Many fossil lungfish have a system of mineralised tubules in the dermis of the snout, branching extensively and radiating towards the epidermis. The tubules anastomose in the superficial layer of the dermis, forming a plexus consisting of two layers of vessels, with branches that expand into pore canals and flask organs, flanked by cosmine nodules where these are present. Traces of this system are found in the Australian lungfish, Neoceratodus forsteri, consisting of branching tubules in the dermis, a double plexus below the epidermis and dermal papillae entering the epidermis without reaching the surface. In $N$. forsteri, the tubules, the plexus and the dermal papillae consist of thick, unmineralised connective tissue, enclosing fine blood vessels packed with lymphocytes. Tissues in the epidermis and the dermis of $N$. forsteri are not associated with deposits of calcium, which is below detectable limits in the skin of the snout at all stages of the life cycle. Canals of the sensory line system, with mechanoreceptors, are separate from the tubules, the plexus and the dermal papillae, as are the electroreceptors in the epidermis. The system of tubules, plexus, dermal papillae and lymphatic capillaries may function to protect the tissues of the snout from infection.
\end{abstract}

(c) 2014 Elsevier Ltd. All rights reserved.

\section{Introduction}

Fossil lungfish have a loose branching system of mineralised tubules in the dermal tissues of the snout, below an ossified "exoskeleton" described as consisting at least in part of a hard tissue called cosmine in some fossil genera. The tubules pass through the dermal tissues of the snout, form a plexus in the outer layers of the dermis and join the pore canals that surround the cosmine nodules in the calcified tissues of the snout (Miles, 1977; Schultze, 1987; Cheng, 1989; Pridmore and Barwick, 1993; Campbell and Wragg, in press). The system of mineralised tubules is present in the dermis of every Devonian dipnoan with suitable preservation, and in a number of crossopterygians such as Porolepis posaniensis (Schultze, 1987). It occurs in basal sarcopterygians like Meemannia eos (Zhu et al., 2010) and in the enigmatic Diabolepis speratus Q3 (Campbell and Barwick, 2001; Chang and Yu, 1984, 1997), but the system is not found in tetrapods (Chang and Yu, 1997; Schultze, 1994). Mineralised tubules have even been found in Ferganoceratodus martini, a Mesozoic lungfish from Thailand (Cavin et al., 2007). Similar branching tubules, which are not mineralised, are

\footnotetext{
* Tel.: +61 7 0400846325; fax: +61 737353822.

E-mail addresses: a.kemp@griffith.edu.au, a.kemp@uq.edu.au
}

present in one living dipnoan, the Australian lungfish, Neoceratodus forsteri. The tubules terminate in a double plexus below the epidermis, and dermal papillae extend into the epidermal tissue (Bemis and Northcutt, 1992). In the Australian lungfish, the tubules appear to be linked with the efferent branchial artery of arch 1, and fill with latex when this vessel is injected (Bemis and Northcutt, 1992). However, at least in N. forsteri, the snout and lips, although often scratched or cut during feeding activities, do not bleed (Kemp, 2012a).

The skin of the Australian lungfish contains several important systems, associated in position but not in function. This contribution examines the structure of the tubule system and its termination within the skin of the snout of the Australian lungfish, as well as the sense organ systems associated with the snout and lips. Although all are found within the tissues of the snout and lips, they are not actually linked, and their functions are separate.

\section{Materials and methods}

Samples of snout, scale and lip tissue from two adult lungfish collected from the Brisbane River in southeast Queensland, and ten laboratory reared juveniles and two subadults from the same source were used for this project. Hatchling and juvenile lungfish were reared from eggs collected in the Brisbane River at Lowood in 
Table 1

Lengths of individual animals used. Subadult and adult specimens have acquisition numbers.

\begin{tabular}{ll}
\hline Stage & Length \\
\hline 45 & Hatchling, $13.8 \mathrm{~mm}$ \\
48 & Hatchling, $18.0 \mathrm{~mm}$ \\
50 & Hatchling, $22.5 \mathrm{~mm}$ \\
52 & Juvenile, $28.1 \mathrm{~mm}$ \\
53 (i) & Juvenile, $34.2 \mathrm{~mm}$ \\
53 (ii) & Juvenile, $36.7 \mathrm{~mm}$ \\
54 & Juvenile, $40.3 \mathrm{~mm}$ \\
57 & Juvenile, $76.5 \mathrm{~mm}$ \\
58 & Juvenile, $86.4 \mathrm{~mm}$ \\
60 & Juvenile, $190 \mathrm{~mm}$ \\
\#AN96-34 & Subadult, $34 \mathrm{~cm}$ \\
\#AN98-45 & Subadult, $45 \mathrm{~cm}$ \\
\#AN99-102 & Adult, $102 \mathrm{~cm}$ \\
\#AN97-114 & Adult, $102 \mathrm{~cm}$ \\
\hline
\end{tabular}

southeast Queensland according to the methods described in Kemp (1981, 1999). Stages follow Kemp (1982, 1999). The hatchlings and juveniles ranged from stage 45 to stage 60 (Table 1 ). The subadult specimens, AN96-34 and AN98-45, were reared in the laboratory. The adult fish, AN99-102 and AN97-114, were caught in the river and heavy wear on the tooth plates confirmed that they were old.

Blocks of tissue, including epidermis and dermis, from adult and subadult lungfish were fixed in $10 \%$ neutral buffered formalin, rinsed in water, and dehydrated in a graded series of ethanols. Specimens from the lips and snout were sectioned with a razor blade to reveal structures in the dermis and in the epidermis. Two planes of section were employed, transverse and sagittal to the long axis of the head. For scanning electron microscopy, processed tissues were dehydrated in a critical point dryer before being mounted on stubs and coated with platinum.

Sections of subadult and adult skin, prepared as described above for scanning electron microscopy, were not coated and were examined in a JEOL 6460 scanning electron microscope fitted with a detector for energy dispersive spectroscopy (EDS analysis).

Blocks of subadult and adult tissue for histology were washed and dehydrated in a graded series of ethanols, and then embedded in Technovit resin (Kemp, 1999) or in Epon Araldite resin, sectioned at $2 \mu \mathrm{m}$ and stained with Toluidine blue in buffer. Heads of hatchling and juvenile lungfish, fixed in neutral buffered formalin, rinsed in water and dehydrated in ethanol, were embedded whole in Technovit resin, then sectioned and stained with $1 \%$ Toluidine blue in phosphate buffered saline. Preparation of dental structures followed the methods outlined in Kemp (2003) and Kemp and Barry (2006).

\section{Results}

\subsection{Definitions}

Structures present in the lungfish snout are illustrated in Fig. 1, to show the relative positions and dimensions of the different structures.

Tubules consist of thick, branching strands of connective tissue radiating through the dermal tissues of the snout and mandible of adult and subadult $N_{\wedge}$ forsteri (Fig. 1A). The tubules have minute foramina along the length, and each one encloses a fine lymphatic vessel packed with lymphocytes. The foramina are $1-5 \mu \mathrm{m}$ in size. Tubules terminate in a double dermal plexus, lying below the epithelium and consisting of connective tissue. The dermal plexus also has minute foramina, $1-5 \mu \mathrm{m}$ in size, and also encloses lymphatic vessels (Fig. 1B). The inner layer of the plexus is intermittent, and the outer layer, closer to the epidermis, is uninterrupted. Dermal papillae arise from
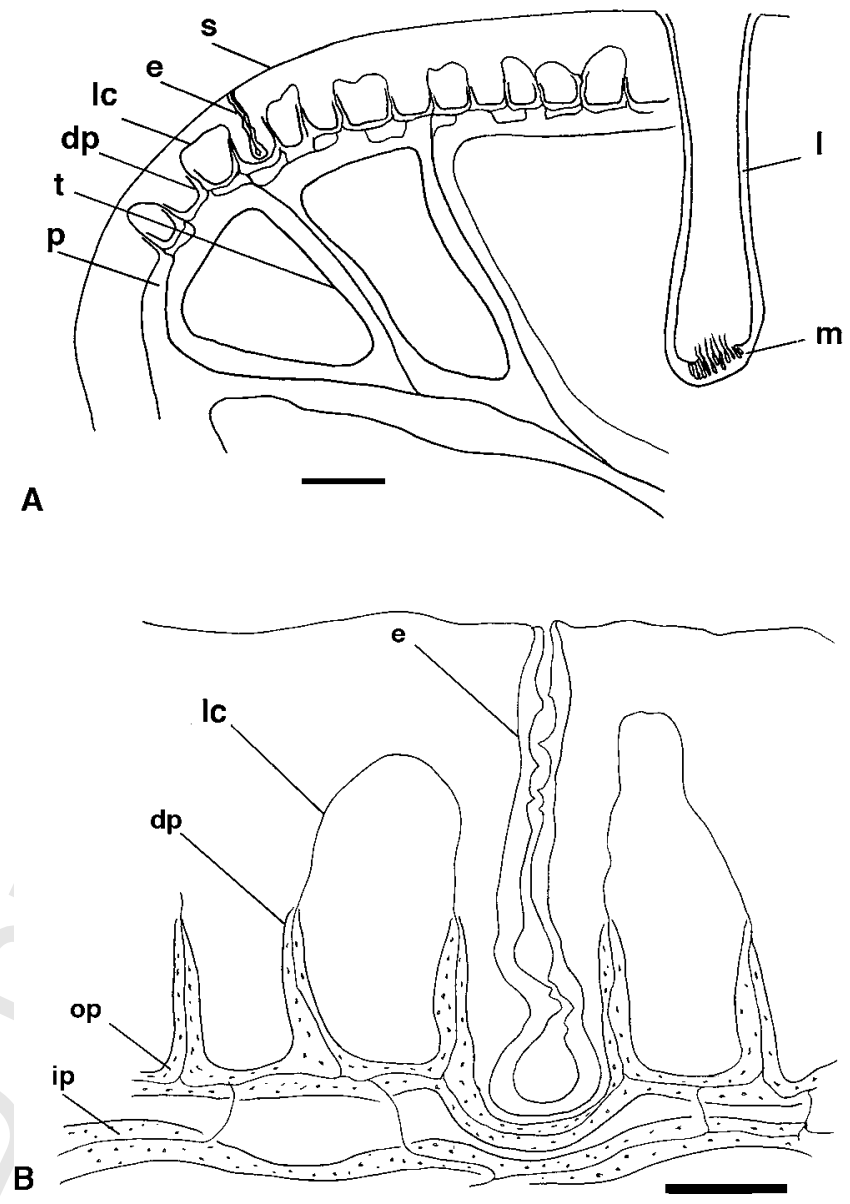

Fig. 1. Drawings to define the structures present in the epidermis and dermis of a lungfish, and their relative dimensions. (A) Low power. Scale bar: $500 \mu \mathrm{m}$. (B) High power of epidermis and plexus. Scale bar $=100 \mu \mathrm{m}$. dp, dermal papilla; e, electroreceptor; l, lateral line canal; lc, lymphatic capillary; $\mathrm{m}$, mechanoreceptor; ip, inner plexus; op, outer plexus; p, plexus; t, tubule.

the outer layer and enter the epidermis. They are conical in shape and made up of connective tissue with minute foramina, $1-5 \mu \mathrm{m}$ in size. They surround a lymphatic capillary. The capillaries emerge from the dermal papillae and form loops among the epithelial tissue, without reaching the surface of the skin (Bemis and Northcutt, 1992: Fig. 12). This system, in a less organised form, is present in young hatchlings and juveniles, and consists of lymphatic capillaries, with no covering of connective tissue, among the other structures present in the dermis. These do not enter the epidermis in young stages.

Sensory (lateral) lines of the head are wide canals deep within the dermis, made up of a single layer of epithelial cells supported by connective tissue (Fig. 1A). At intervals along the length of the canal are mechanoreceptors. The sensory lines and the tubules, the plexus and the dermal papillae in the living lungfish may be found in the same anatomical region of the head, but there are no functional or anatomical connections between them.

Electroreceptors (ampullary pits) are small sensory organs, confined to the epidermis or to superficial layers of the dermis (Fig. 1B). On the snout they are single, and on the dorsal, lateral and ventral surfaces of the head they are arranged in pit lines (Kemp, 1999). Rows of electroreceptors run above and below the lateral line of the trunk (Kemp, 2012b). Despite a close topographic association with the dermal papillae and the sensory lines 
of the head, electroreceptors are separate in structure and in function.

\subsection{The skin}

The skin of the snout and lips in the living Australian lungfish is soft, and free of scales at all stages of the life cycle (Kemp, 2012b). In external view, the skin of the snout is pitted, with perforations of various sizes, for goblet cells and sense organs, and apart from this, individual epithelial cells are visible in surface view (Fig. 2). In early stages, the surfaces of the epidermal cells are highly structured. The openings of electroreceptor organs are surrounded by cells with a convoluted pattern of raised lines (Fig. 2A) and, in early stages before the lateral line canals develop, the mechanoreceptors on the skin surface are surrounded by a corona of cells with small pustules, and cells more typical of skin cells with the convoluted pattern surround them (Fig. 2B). In older fish, cell surface markings have disappeared (Fig. 2C), and the outer epidermal cells are rounded and smooth. Small pits are scattered randomly among the epithelial cells, probably the openings of electroreceptor organs, or perhaps of goblet cells (Fig. 2C).

In hatchling and juvenile lungfish, between stages 48 and 60 , the epidermis has several layers of cells. Subadult and adult lungfish have many layers of cells (Fig. 3). Skin of the snout and lips is particularly thick. Most of the cells form a transporting epithelium, and some produce mucus, with openings to the external surface. These may be aligned (Fig. 3A), but are usually randomly arranged. The epidermis of adult fish is divided into blocks of cells by the formation of dermal papillae (Fig. 3B), some of which surround electroreceptor organs. Below the epidermis is the dermal plexus, enclosing lymphatic capillaries. No mineralised tissues are present at any time in the thickness of the epidermis or in the underlying dermal tissues of the snout and lips, and no cellular configurations suggestive of the formation of a hard tissue element such as cosmine, denteons or bone can be found among the epidermal cells (Fig. 3). Calcium, a major constituent of the biogenic hydroxylapatite found in the hard tissues of vertebrates, is below detectable limits in the epidermis and dermis.

\subsection{Mechanoreceptors and electroreceptors}

The skin of living lungfish has numerous sense organs that open on the external surface. Electroreceptor ampullary pits lie in the epidermis, or within the dermis close to the epidermis, and the much larger sensory line canals, including mechanoreceptor organs, are deep within the dermal tissues, opening at intervals to the surface of the skin. In living lungfish, these two systems of sense organs are separate in structure and in function, despite being associated topographically and both being innervated by nerve $\mathrm{V}$ (Northcutt, 1986; Joergensen, 2011).

Lateral lines of the head begin to appear in hatchling $N$. forsteri at stage 42 and at first consist of superficial shallow canals with a few mechanoreceptor sense organs distributed along their length (Fig. 4A). As the hatchling grows, at around stage 47, the canals sink into the skin surface and the mechanoreceptor sense organs are gradually enclosed, with openings along the length of the canal (Fig. 4B). In juveniles and adults, mechanoreceptors are confined to deep and wide sensory canals, running in a defined pattern over the head (Pehrson, 1949; Kemp, 1999), except on the tip of the snout, where the mechanoreceptors may still be superficial. The canals are huge, at least $200 \mu \mathrm{m}$ in diameter and often larger. Most lie deep within the dermis (Fig. 5A). A single layer of epidermal cells supported by connective tissue forms the canal, and large mechanoreceptors, situated at intervals along the base of the canal, consist of a cluster of columnar cells derived from the epithelium, with stereocilia arising from the surface of each cell (Fig. $4 \mathrm{~A}$ and $\mathrm{B}$ ).
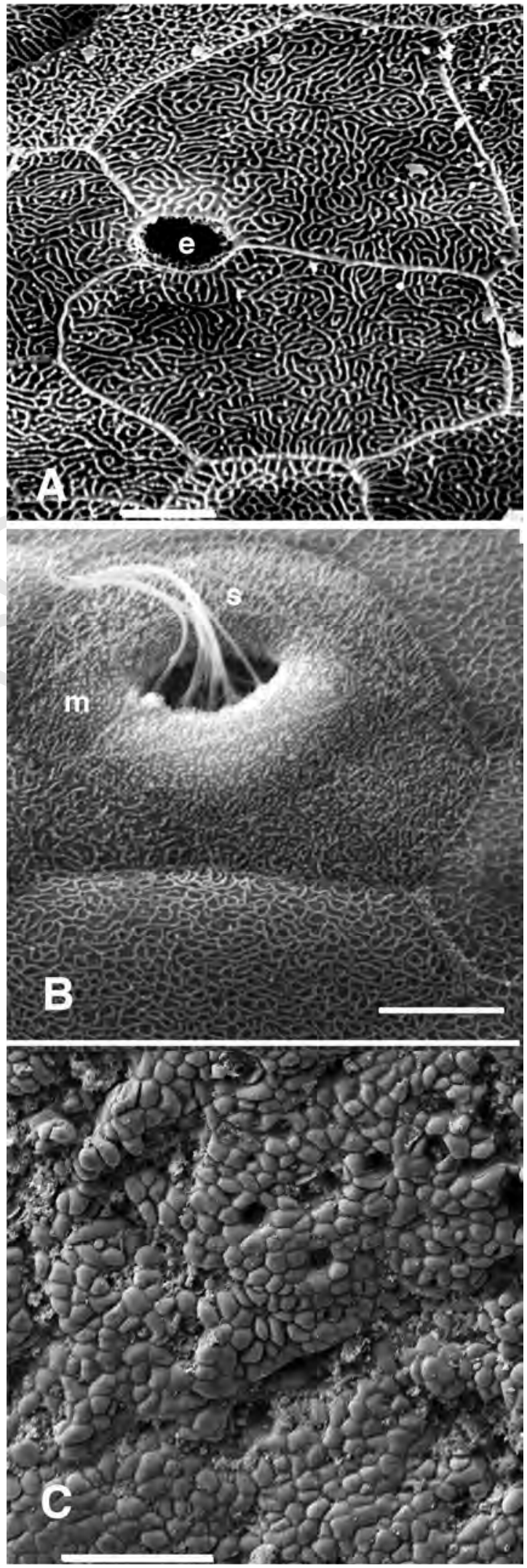

Fig. 2. The surface of the skin. (A) Surface view of an electroreceptor in the skin of a lungfish of stage 58 . The skin cell surfaces are highly structured, and minute papillae encircle the opening of the electroreceptor. Scale bar $=5 \mu \mathrm{m}$. (B) Surface view of a mechanoreceptor in the skin of a lungfish of stage 46. Specialised cells surround the opening of the mechanoreceptor, from which long stereocilia emerge. Cell surfaces are highly structured. Scale bar $=20 \mu \mathrm{m}$. (C) Surface view of adult skin showing numerous small orifices, some for electroreceptors and some for goblet cells. The cell surfaces are smooth. Scale bar $=100 \mu \mathrm{m}$. e, electroreceptor; m, mechanoreceptor; s, 

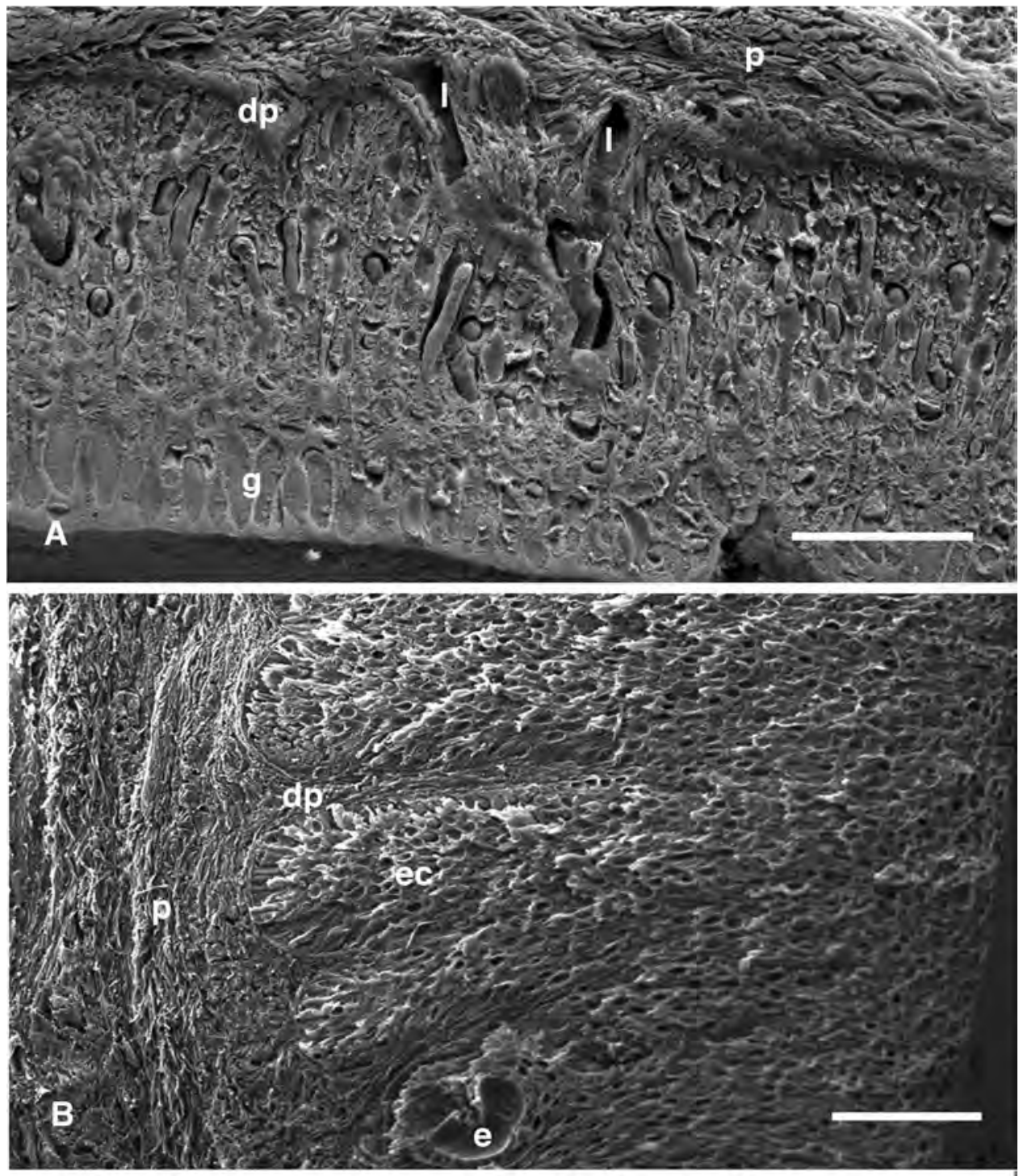

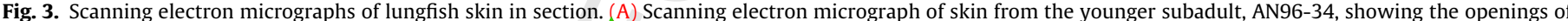

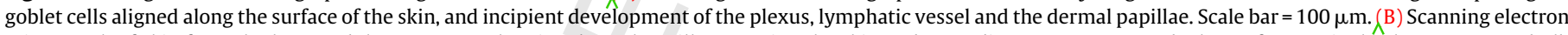

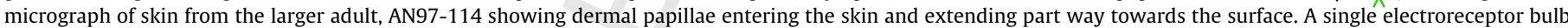

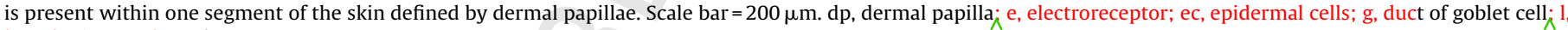
lymphatic vessel; p, plexus.

Modified epithelial cells, also columnar, surround and support the mass of sensory cells (Fig. 4A and B). In adult N. forsteri, the single openings of the sensory canals are divided into clusters of openings on the head (Jarvik, 1981). This change, from single openings to clusters, marks the transition from juvenile to subadult (Kemp, 1999).

Electroreceptive ampullary organs are present in the epidermis and superficial areas of the dermis of lungfish (Figs. 5 and 6), first appearing at stage 47. Active receptors consist of a double layer of cuboidal cells that form a hollow ball, situated below the collagen of the epidermal/dermal junction or deeper, within the dermis (Figs. 5 and 6). The position is variable, especially in the snout (Fig. 6). Cells lining the bulb have minute projections from the surface (Fig. 6A), and some of the cells show evidence of cell division (Fig. 6B), not common elsewhere among epidermal and dermal tissues. A narrow duct, lined by a single layer of epithelial cells, extends from the ball of cells to the surface of the epithelium, where it opens as a small circular pit surrounded by tiny papillae, at least in early stages. Projections from the cell walls of the duct turn the structure into a loose spiral (Figs. 5B, C, and 6). Inside the orifice there may be a small valve, capable of closing the duct (Fig. 5B). The bulb and duct may contain a diffuse secretion consisting of proteoglycan (Fig. 6A), but are usually empty in prepared specimens. Organisation of the electroreceptor is variable, and sometimes details of the arrangement are imprecise (Fig. 5C).

The structure of active electroreceptors is distinctive and similar in every stage of development, although the duct to the exterior has to increase in length as the epidermis grows thicker. Electroreceptors are numerous below and within the epidermis of the snout and lips (Fig. 6C), and are always separate from the mechanosensory lateral line canals. Most of the electroreceptors are $40-50 \mu \mathrm{m}$ in diameter, with the duct about $20 \mu \mathrm{m}$ wide, but electroreceptors and ducts on the tip of the snout are often larger, up to 80 and $40 \mu \mathrm{m}$ respectively (Fig. 6D).

A second form of electroreceptor organ is also present in the skin, from stage 53 onwards. These have a large bulb, consisting of a single layer of cuboidal cells with a smooth lining, which extends into a wide straight duct that connects with the surface of the skin 


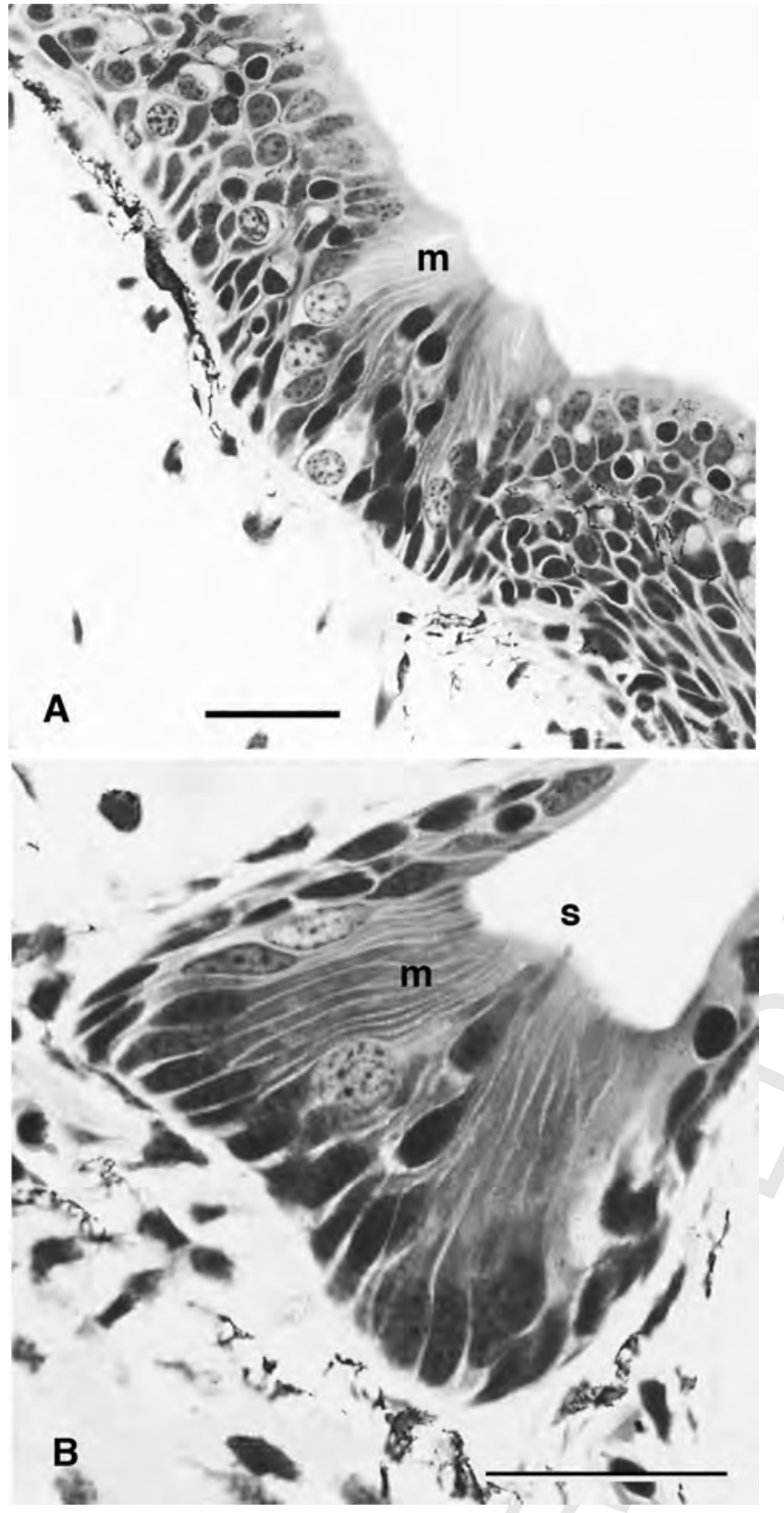

Fig. 4. Light micrographs of mechanoreceptors from hatchling skin. (A) Superficial mechanoreceptor, from the tip of the snout in a hatchling of stage 54. (B) A mechanoreceptor in the supraorbital line of a hatchling of stage 54 . Scale bars $\mathrm{A}=200 \mu \mathrm{m} \wedge \mathrm{B}=100 \mu \mathrm{m}$. m, mechanoreceptor; s, stereocilium.

(Figs. 5D and 6C, D). These electroreceptors are up to $120 \mu \mathrm{m}$ in diameter, and the duct is $70 \mu \mathrm{m}$ in diameter. Small spherical inclusions, up to $5 \mu \mathrm{m}$ in size, which stain for glycoproteins, are present in the bulb and in the duct passing to the surface (Fig. 6C and D). A few of these inclusions are present on the skin surface, as if they had been ejected from the duct. Occasionally, an electroreceptor with a structured duct and with spherical inclusions can be found among the sense organs, particularly in the snout. The second type of electroreceptor opens to the surface via a large rough orifice, without a valve or papillae. No cell divisions are present among the electroreceptors that have large bulbs and inclusions, and this type of electroreceptor is not found in hatchlings up to stage 52. At these early stages, all of the electroreceptors are of the first, more common, type.
Electroreceptors in the specimens examined in this study may be associated in older fish with the blocks of epidermal tissue created by the passage of dermal papillae (Fig. 5D), although they may be independent. On the dorsal, lateral and ventral surfaces of the head, electroreceptors of both types are arranged in pit lines that extend from the lateral line canals (Pehrson, 1949; Kemp, 1999). Apart from a topographic association, the electroreceptor organs of the pit lines have no functional relationship with the mechanoreceptors of the lateral line, and the structure of the electroreceptors in the pit lines is identical with the structure of the isolated organs on the snout.

\subsection{The fubule system and the lymphatic capillaries}

Lymphatic capillaries are present in the dermal connective tissue of hatchlings as young as stage 48 , just before the fish undergoes the postural change at stage 50 and starts to feed actively among water plants (Kemp, 1996). They are narrow vessels, and lie among the diffuse collagen and elastin fibrils, sense organs, nerves, and electroreceptors in the snout. The lymphatic capillaries are up to $25 \mu \mathrm{m}$ in width, with thin walls, only as wide as the cells they contain. These are large and elongated, with clear cytoplasm and dark oval nuclei that fill the lumen of the tubule (Fig. 7A). Melanocytes lie below the epidermis, in the most superficial layer of the dermis, and a few have invaded the epidermal tissues. Above the melanocyte layer, and in contact with epidermal cells, is a dense layer of collagen, about $5 \mu \mathrm{m}$ thick. The lymphatic vessels do not penetrate the collagen layer at this stage, and are confined to the dermis.

In juvenile lungfish of stage 57 , the lymphatic capillaries form a loose and tangled network among the cellular bulbs that make up the dermal portion of the electroreceptor organs, and the canals of the sensory line system (Fig. 7B). The walls of the lymphatic capillaries are still thin. They are found among most dermal tissues, and are particularly dense close to the epidermis of the snout. As in hatchlings (stages 48-50), there is no trace of intrusion of lymphatic capillaries into the epidermis, nor is there any apparent organisation of a plexus at the dermal-epidermal boundary. This begins to appear in subadult fish, and is extensive in adults. The capillaries containing lymphocytes follow a tortuous path within the plexus (Fig. 7C). Occasionally a separate vessel containing red blood cells, flat with a prominent bulge for the nucleus, is present among the dermal tissues.

Lymphatic vessels with enclosed lymphocytes begin to invade the epidermal tissues in young sub adults (Fig. 8A). At the same time, a system of branching tubules, up to $200 \mu \mathrm{m}$ in diameter and with fibrous walls and minute holes $1-5 \mu \mathrm{m}$ in size, passes through the dermal collagen towards the epidermis, not apparent in juveniles up to stage 60, but present in subadult lungfish (Fig. 9A). They join to form a network in the superficial layers of the dermis, among the dermal collagen and the melanocytes, and reach the plexus below the collagen layer (Fig. 8B). The plexus is not, in the smaller specimen, AN96-34, particularly obvious or regular in appearance. In the larger subadult fish, AN98-45, the plexus in both upper and lower lips is well formed, approaching the appearance of the adult, and the vessels that enter the epidermis are enclosed in thick connective tissue (Fig. 8B), the dermal papillae of Bemis and Northcutt (1992). In adults, dermal papillae arise from the plexus, and are aligned within the epidermis (Fig. 9B), but are not often associated with electroreceptive organs.

In older lungfish, the tubules that pass through the dermis terminate in a thick layer of fibrous connective tissue containing fine lymphatic vessels, mostly running around the snout and lower lip, and some connecting the two layers at right angles to this direction (Fig. 8B). The fibrous connective tissue contains no cells, but is pitted with small perforations. Dermal papillae, also appearing fibrous with small perforations, extend from the outermost layer of 

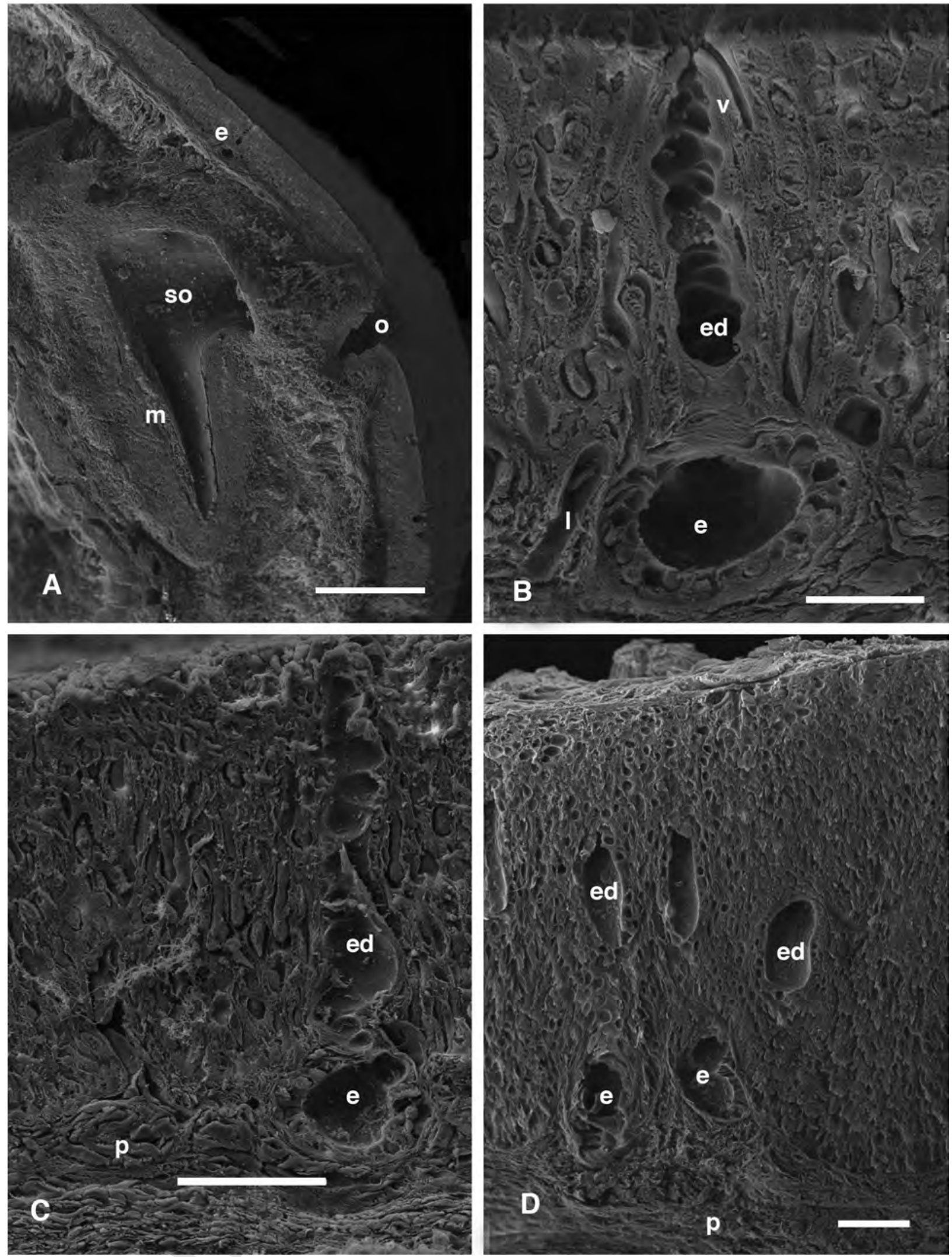

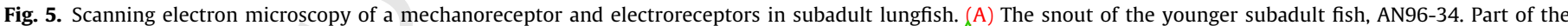

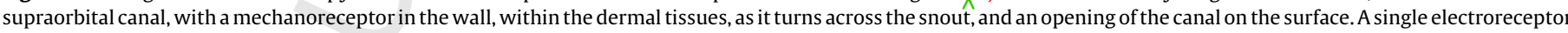

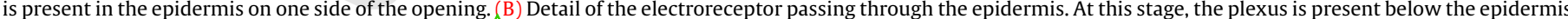

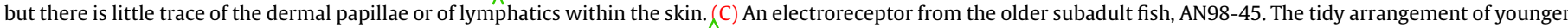

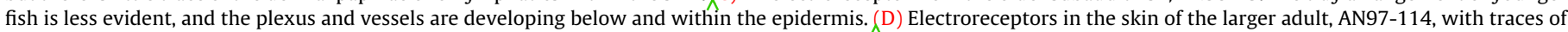

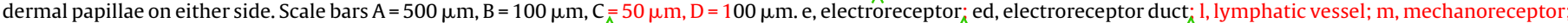
o, opening of canal; p, plexus; so, supraorbital canal; v, valve.

Please cite this article in press as: Kemp, A., Skin structure in the snout of the Australian lungfish, Neoceratodus forsteri (Osteichthyes: Dipnoi). Tissue Cell (2014), http://dx.doi.org/10.1016/j.tice.2014.07.004 

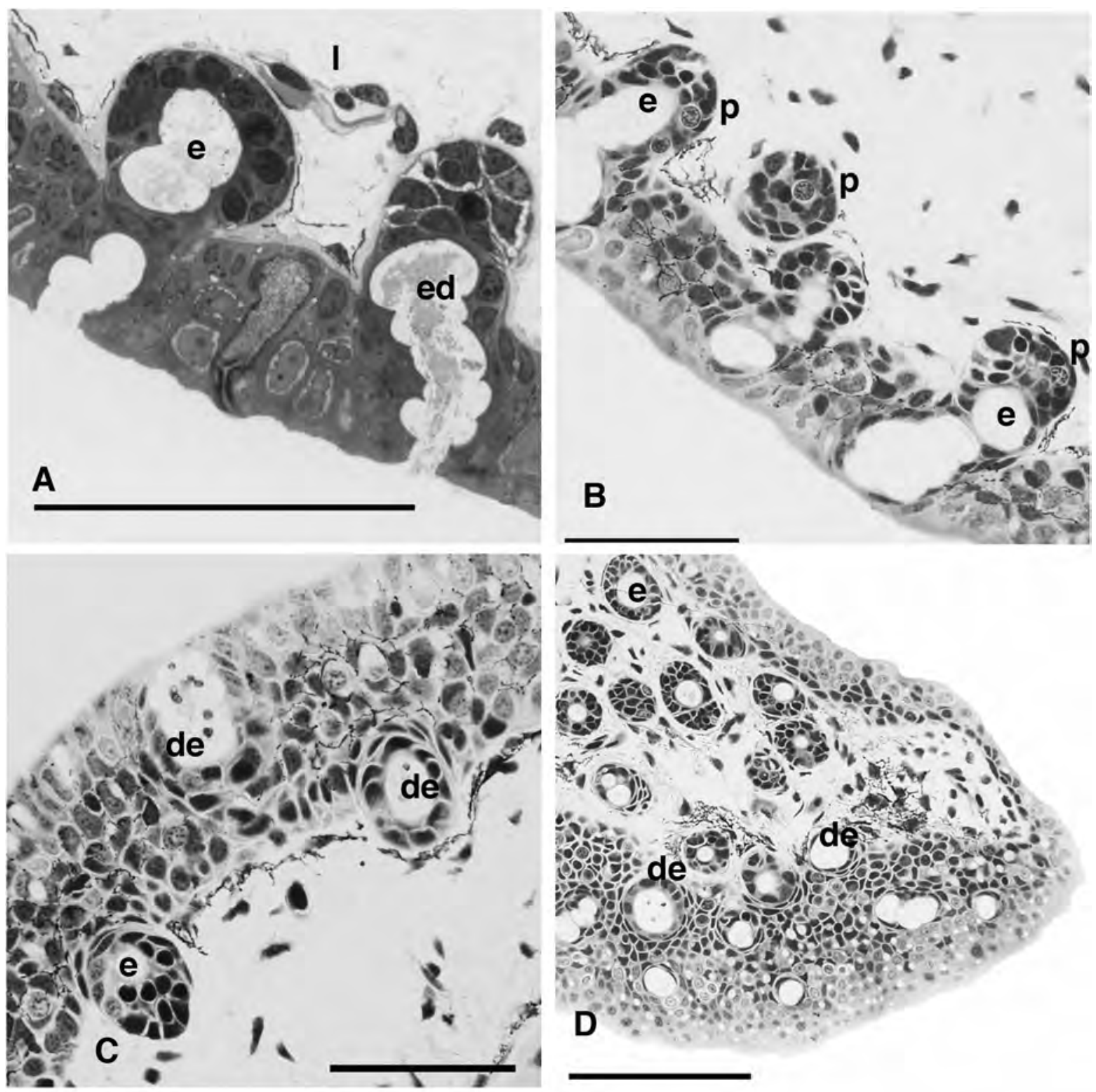

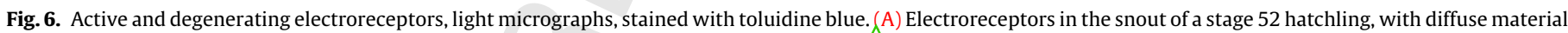

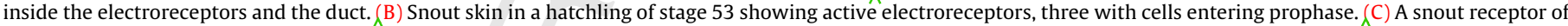

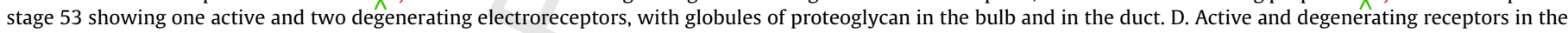

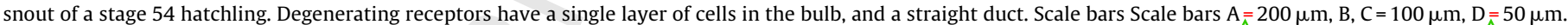
de, degenerating electroreceptors; e, electroreceptors; p, prophase nuclei.

connective tissue and pass into the epidermis (Fig. 9B). At intervals within the epidermis, the dermal papillae divide the epidermis into blocks (Fig. 9B). The papillae reach about half way into the thickness of the tissue, and may divide. Where they terminate, fine lymphatic vessels without a connective tissue coat emerge (Fig. 10A), and these join to form loops among the epidermal cells. Between these intervals, defined by the branches that extend from the plexus, the epidermis is undivided. The fine lymphatic branches arising from the dermal papillae are more numerous than capillaries with red blood cells, which are scarce and scattered randomly through the skin tissues (Fig. 10A).

The epidermis of the older lungfish is up to 500 microns thick, with many layers of cells, of the same cell types as in younger stages (Fig. 9B). There are numerous goblet cells among the transporting epithelial cells. There is no particular arrangement among the goblet cells in either of the two adult specimens examined (Fig. 10B).
Within the epidermis, cells are aligned around the connective tissue that extends into the epidermis, in contact with each other and with the collagen. A similar alignment of epidermal cells is apparent in the cells in contact with the connective tissue of the plexus (Figs. 3B, 8B, and 9B). All of these cells are still part of the epidermis, and are not involved with the connective tissue of the plexus or the dermal papillae. Nor is there any sign of secreted material within the epidermis that could be a precursor of a mineralised element. The connective tissue of the plexus and the dermal papillae is not cellular. It has the appearance of an extracellular matrix, but without any trace of mineral.

\subsection{Denteons and dermal papillae}

In transverse sections of basal regions of the epidermis, the dermal papillae consist of a vessel containing lymphocytes, surrounded by thick connective tissue and a corona of epidermal cells,

Please cite this article in press as: Kemp, A., Skin structure in the snout of the Australian lungfish, Neoceratodus forsteri (Osteichthyes: Dipnoi). Tissue Cell (2014), http://dx.doi.org/10.1016/j.tice.2014.07.004 


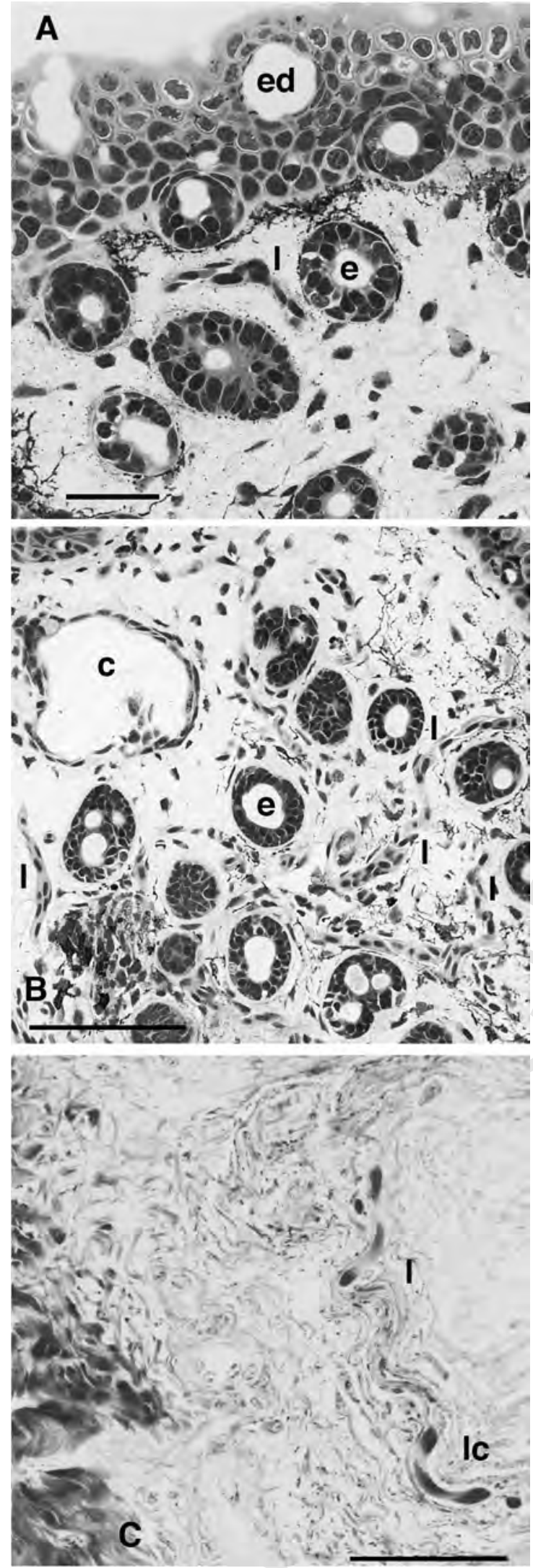

Fig. 7. Structures in the lungfish snout, light micrographs, stained with toluidine blue. (A) Snout skin in transverse section of a hatchling of stage 50 showing active receptors, ducts and a lymphatic vessel. (B) Section through the dermis of the snout in a juvenile of stage 58 , showing electroreceptors, sensory line canal and lymphatic vessels. No capillaries containing red blood cells are present. (C) Lymphatic vessel containing lymphocytes within connective tissue of the plexus, in the larger adult (AN97-114). Scale bars $A=100 \mu \mathrm{m}, B, C=200 \mu \mathrm{m}$. c, canal of sensory line; ed, duct
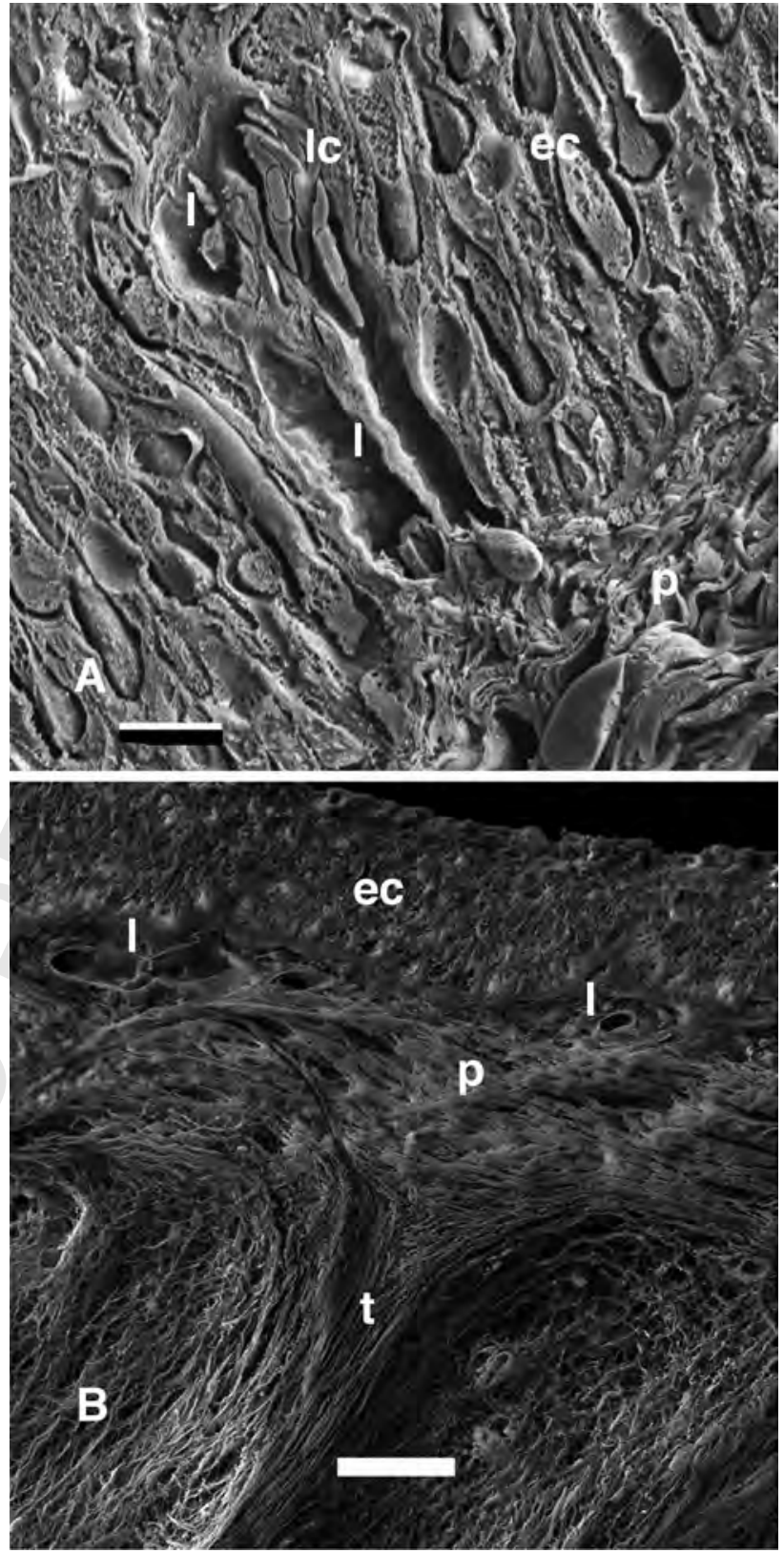

Fig. 8. Scanning electron micrographs of the tubules and dermal papillae in subadults and adults. (A) Sagittal section through the skin of the younger subadult, AN96-34, showing incipient development of dermal papillae and a lymphatic loop with white blood cells in the epidermis. (B) Tubule entering the plexus, with lymphatic vessels, in the skin of AN98-45, transverse section. Scale bars $A=20 \mu \mathrm{m}$, $\mathrm{B}=200 \mu \mathrm{m}$. ec, epithelial cells; 1, lymphatic vessel; lc, lymphocytes; p, plexus; $t$ tubule.

all arranged around the outside of the dermal papilla (Fig. 11A). In external layers of the epidermis the connective tissue coat disappears, and a thin membrane encloses the lymphocytes. There is no trace of mineralised tissue around or among the corona of cells, and no indication of a soft tissue structure that could form the precursor of cosmine.

Lungfish tooth plates are made up of a number of different tissues, each integral to the structure, growth and function of the tooth plate (Kemp, 2001, 2003; Barry and Kemp, 2007; Kemp and Barry, 2006; Lison, 1941; Ishiyama and Teraki, 1990). Most of the tooth plate is made up of interdenteonal dentine containing sparse cell processes and transected by denteons lined by circumdenteonal dentine. 

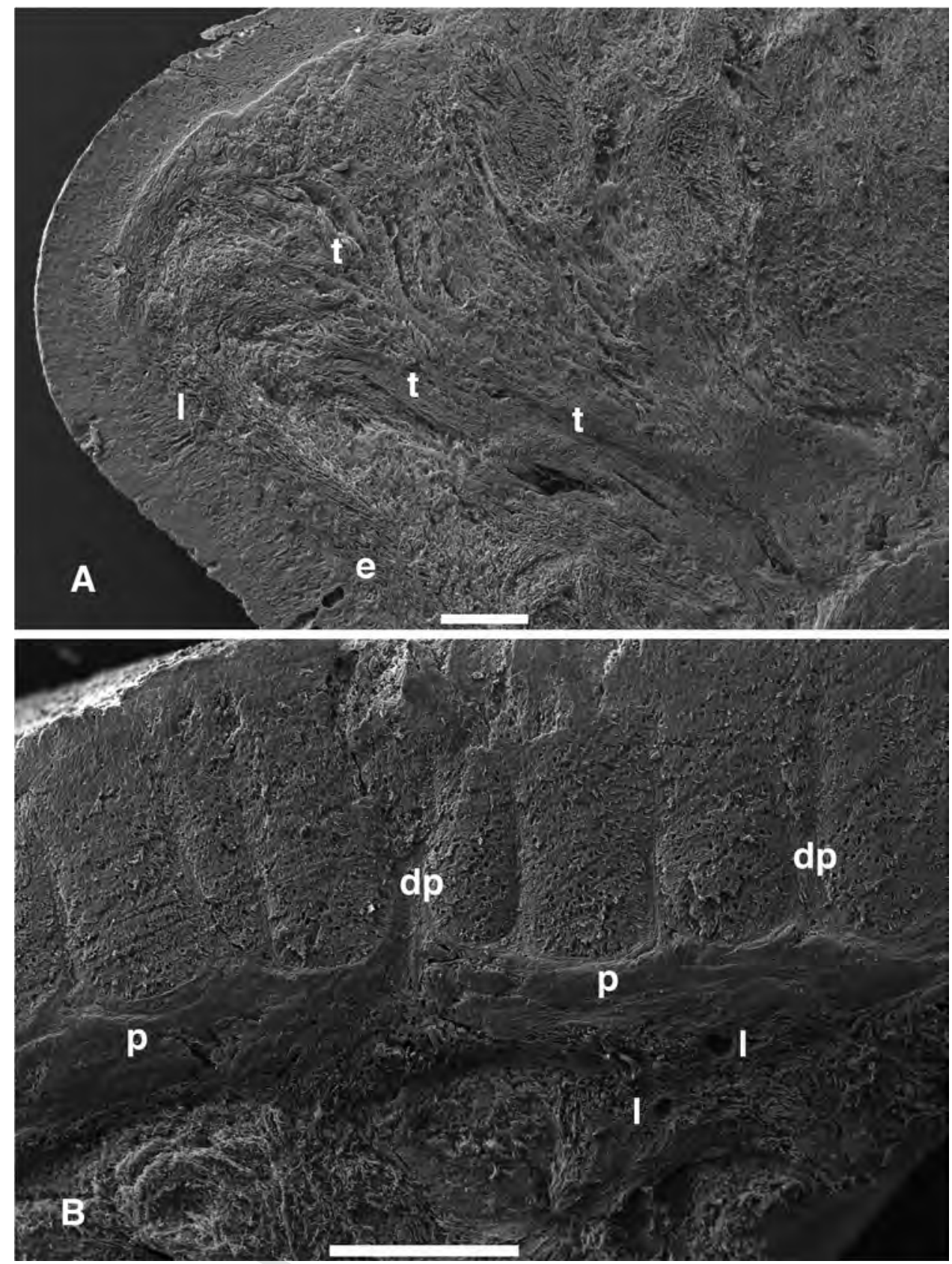

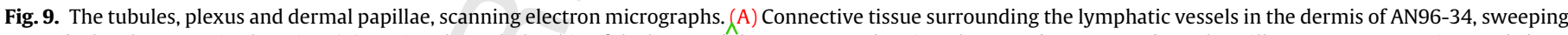

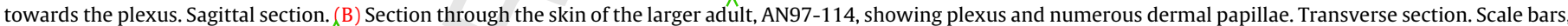
$\mathrm{A}=100 \mu \mathrm{m}, \mathrm{B}=500 \mu \mathrm{m}$. dp $\mathrm{dermal}_{\mathrm{A}}$ papillae; e, electroreceptor; l, lymphatic vessel; p, plexus; t, tubule.

Denteons that pass through the interdenteonal dentine of derived lungfish, such as $N$. forsteri, are straight tubules with no branches. They are perpendicular to the surface of the tooth plate and lined with a continuous layer of large secretory cells that maintain the mineralised tissue, known as circumdenteonal dentine. This dental tissue consists of layers of fine needle shaped crystals of calcium hydroxylapatite arranged around the circumference of the denteon (Kemp and Barry, 2006). All of the cells associated with the secretion of circumdenteonal dentine are enclosed within the denteon (Fig. 11B). The cells surround a capillary loop, with at least two thin walled capillaries, and sparse nucleated red blood cells are present within them. This arrangement is particularly obvious in sections close to the pulp cavity where the denteon is actively forming (Fig. 11B). As the denteon approaches the surface of the tooth plate, the secretory cells lose their activity and become crenated.

\section{Discussion}

Apart from the secretory goblet cells, and the cells that form a transporting epithelium, the skin of the snout and lips of living lungfish includes three systems, effectively separate although confined within a small area. Two are sensory, and one is protective. One sensory system is deep within the dermis, and includes groups of mechanoreceptor cells enclosed in sensory canals, with sparse openings to the surface. The second consists of small separate electroreceptor organs, within the epidermis and most superficial layers of the dermis, and incidentally partially associated in position at least with the protective system. This involves branching tubules in the dermis, a plexus of vessels at the epidermal dermal boundary and dermal papillae that enter the epidermis, all enclosing fine lymphatic vessels containing lymphocytes. 

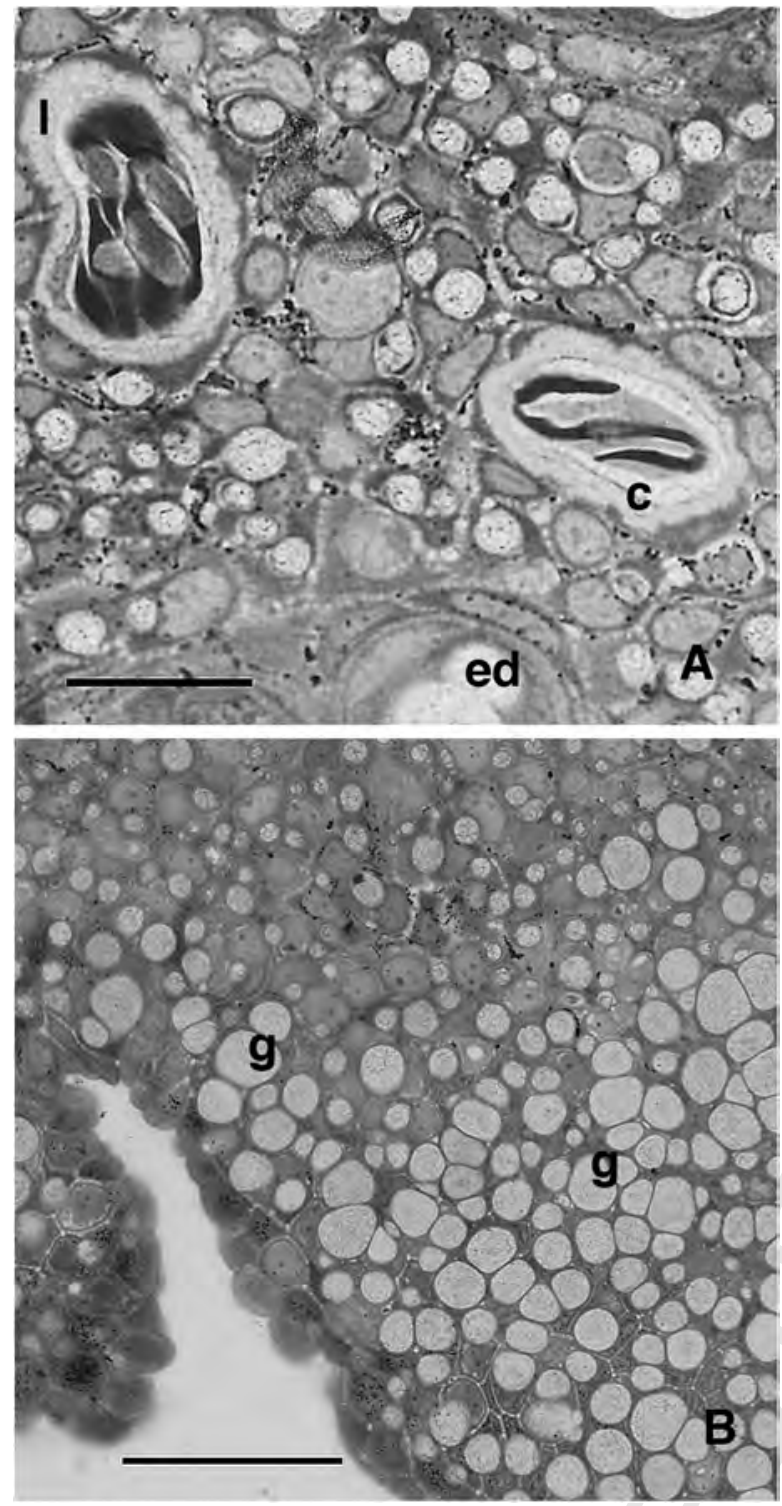

Fig. 10. Light micrographs of skin, goblet cells and vessels, araldite section, stained with toluidine blue. (A) Transverse section of adult skin near the surface showing electroreceptor ducts, goblet cell ducts, lymphatic vessel with lymphocytes and capillary with erythrocytes. (B) A frontal section close to the surface of the epidermis of an adult, AN97-114, showing ducts of goblet cells. Scale bars A, B $=100 \mu \mathrm{m}$. c, capillary with erythrocytes; ed, duct of electroreceptor; $g$, ducts of goblet cells; 1 , lymphatic vessel with lymphocytes.

Mechanoreceptors are distinct from the electroreceptor ampullary pits, whether these are scattered on the snout and lips or associated in pit lines and along the trunk. Both types of sense organ develop from epidermal placodes and are innervated by branches of nerve $\mathrm{V}$ (Joergensen, 2011). However, they differ markedly in structure and modulate different senses. The mechanoreceptors are part of the acousticolateralis system. They pick up mechanical signals in the water and have a dual innervation, afferent and efferent. Mechanoreceptors are large, and mostly confined within the lateral line canal buried within the dermis. They consist of a mass of columnar epithelial cells with stereocilia, supported by columnar cells with no stereocilia. In the living Australian lungfish, they are remote from the dermal tubules, the connective tissue plexus and the dermal papillae and associated lymphatic vessels, and from the electroreceptors.

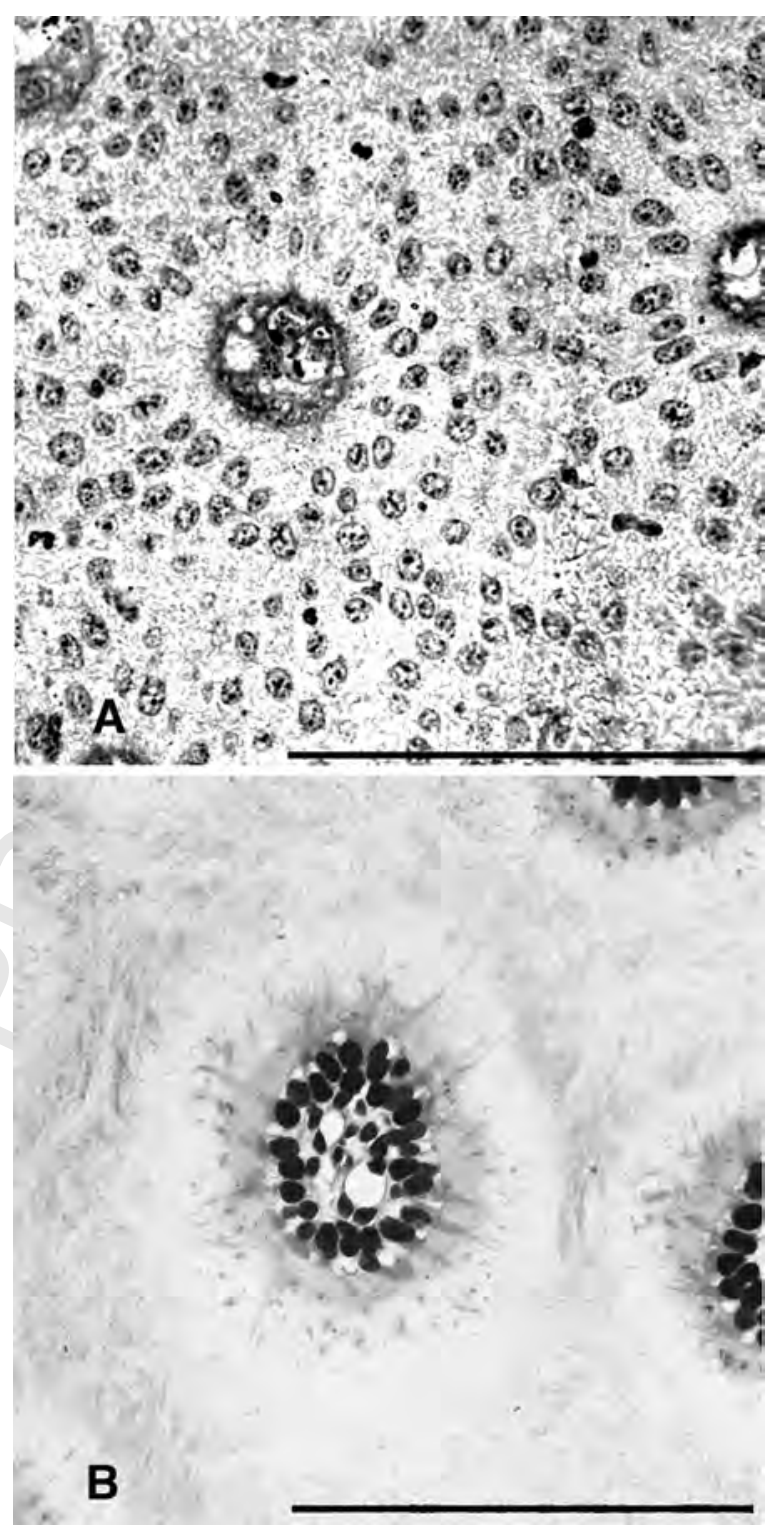

Fig. 11. Comparison of a dermal papilla and a denteon. (A) A dermal papilla within the epidermis of the larger adult, AN97-114, in transverse section showing cells and connective tissue surrounding a lymphatic vessel within the papilla. Araldite section, toluidine blue stain. (B) A denteon close to the pulp cavity of the smaller subadult, AN96-34, in transverse section, showing arrangement of cells secreting hard tissue within the denteon, and enclosing capillaries. Technovit section, toluidine blue stain. There are no cells around the denteon; all are enclosed within the structure. Scale bars $A, B=200 \mu \mathrm{m}$.

Electroreceptors are small, confined to the superficial layers of the dermis or the epidermis, and have a single innervation (Northcutt, 1986). They are sensitive to weak electric currents in the water, possibly given off by prey animals (Roth, 1973; Roth and Tscharntke, 1976; Bullock et al., 1983; Collin and Whitehead, 2004; Kramer, 1996). The commonest form of electroreceptor has a double layer of cells within the bulb, with traces of cell division, and is lined by sensory cells. The bulb enters a narrow and convoluted duct, occasionally closed with a valve at the surface of the epithelium. Signs of a diffuse secretion may be present within the bulb and the duct, and the sensory cells include a kinocilium (Joergensen, 1984, 2011). The less common form of electroreceptor is not equivalent to any of the three types identified by Joergensen (1984) and is not a new kind of receptor, but is evidence of turnover of these organs within the skin. The bulb has a single layer of cells, and the 
duct is wide with no structure. It contains spherules of glycoprotein instead of the usual diffuse mass. The opening to the surface is rough. They show no evidence of cell division, and no sign of receptor cells. The spherules of secretion that they contain may represent ejection of used glycoproteins, and these can be found on the skin surface.

There is no evidence of isolated electroreceptors in the heavily ossified exoskeleton of fossil lungfish, and the entire system of tubules, plexus and flask organs into which the vessels of the plexus open, has been described as sensory in Dipnorhynchus, a large fossil lungfish from the Devonian of New South Wales (Campbell and Wragg, in press). However, the mineralised tissues in the snout of fossils must have been covered in an epidermis in life, and it is likely that any sense organ equivalent to the electroreceptors of living lungfish was also confined to the epidermis in fossils, as are most of the electroreceptor ampullary pits in extant species. They may have been contained within the pore canals and the flask organs, and this could explain the openings of these structures to the surface. However, without preserved soft tissues, this is only speculation. Mechanoreceptors are present in fossils, and, as in living lungfish, are situated in large canals deep in the dermal tissues (Cheng, 1989).

Many Devonian fossils have a system of tubules below the skin, in addition to the large sensory line canals that house mechanoreceptor organs (Cheng, 1989; Schultze, 1987). The mineralised tubules are found in dipnoans and in related sarcopterygian fishes, but are unknown in tetrapods (Schultze, 1987, 1994). They are also present in the enigmatic Diabolepis speratus (Schultze, 1994) and in the stem sarcopterygian Meemania eos (Zhu et al., 2010). In Devonian species, the walls of the tubules are perforated and mineralised, and the tissues that surround them are not. These have been figured and described for numerous Devonian fossils (Cheng, 1989; Miles, 1977; Campbell and Barwick, 1994; Schultze, 1987, 1994). Cheng (1989), working with several Australian Devonian species, including Chirodipterus australis and Griphognathus whitei, has described the tubules as ossified, with two layers and containing many cells. They may join the pore canal system in the skin. Radiographs suggest that the tubules are connected with the lateral line sensory system of the head, but the illustrations are confusing and the tubules may simply overlie the sensory line canal, or the connection is actually with a larger branch of the tubule, and not the sensory line (Cheng, 1989: Figs. 6 and 10).

Later Palaeozoic dipnoans may have had a system of tubules, but the heavy mineralisation of earlier fossil species is lost, as is evident in most late Devonian dipnoans such as Sagenodus copeanus (Schultze and Chorn, 1997), although tubules in the Carboniferous osteolepiform from Queensland, Cladarosymblema narriense (Fox et al., 1995) are also mineralised. Branching tubules in the dermis of the snout have recently been described in Ferganoceratodus martini, a Triassic lungfish from Thailand (Cavin et al., 2007). These are mineralised, with a morphology similar to that of the system found in Devonian dipnoans. Unfortunately, preservation of most fossils in later deposits of the Palaeozoic and in the Mesozoic is usually fragmentary, and confined to isolated skull bones, jaws and tooth plates. On the few occasions when parts of the whole head are preserved (Teller, 1891), tubules are apparently absent, as in the Triassic fossil Ceratodus sturii.

The system of tubules, plexus and dermal papillae in lungfish has been associated with the production of cosmine in the scales and skin of early vertebrates, and with the denteons in the dentition of derived dipnoans (Bemis and Northcutt, 1992). Cosmine consists of nodules, often covered by enamel or enameloid, and containing branching canals that radiate through the tissue, becoming smaller and smaller as they approach the surface (Denison, 1968; Pridmore and Barwick, 1993; Schultze, 1987). Cosmine must have been secreted by cells within a pulp cavity, with branching tubules arising from a focal point in the base of the mineralised nodule. It is confined to the most superficial skin and scales of some fossil Sarcopterygii and Actinopterygii (Schultze, 1987), such as Uranolophus (Denison, 1968), Chirodipterus and Griphognathus (Pridmore and Barwick, 1993). Cosmine nodules may also be found buried by subsequent growth of additional elements (Denison, 1968). It is not present in the scales and epidermis of living lungfish (Kemp, 2012b; Kerr, 1955; Zylberberg, 1988). Cosmine is located between the pore canals and flask organs where the tubules terminate in fossils. $N_{\wedge}$ forsteri may have no cosmine, but it retains the tubules, the plexus of vessels and the dermal papillae (Bemis and Northcutt, 1992).

Bemis and Northcutt (1992) suggest that the dermal papillae are equivalent to the pulp canals passing through the denteons of lungfish tooth plates, because they are found in the skin, and in Devonian lungfish the skin is associated with cosmine. They speculate that calcified elements, associated with the dermal papillae and possibly related to cosmine, are likely to be found in the skin of the snout and lips of fully grown adult lungfish, larger and presumably older than the specimens they examined. No trace of mineralised elements are found in the skin of older lungfish, and the fine structure of cosmine has little in common with the hard tissue associated with denteons that form such an obvious feature of the interdenteonal dentine of the tooth plates of many dipnoans (Kemp, 2001, 2003; Kemp and Barry, 2006; Lison, 1941). Denteons consist of a ring of circumdenteonal dentine, enclosing secretory cells and a capillary loop containing red blood cells. The secretory cells are flat, with oval nuclei and slender processes entering the circumdenteonal dentine (Kemp, 2003; Kemp and Barry, 2006). The denteon is of uniform diameter and passes from the pulp cavity of the tooth plate, through the interdenteonal dentine, to the occlusal surface. Cells associated with dermal papillae are not enclosed within the structure. They have rounded nuclei and surround the papilla. The dermal papillae are completely different from the denteons of the tooth plates.

Dermal papillae in $N$. forsteri consist of connective tissue enclosing a narrow lymphatic vessel containing lymphocytes. The lymphatic vessel emerges from the dermal papilla to join another lymphatic capillary, and form a loop. Encircling the dermal papilla are layers of epidermal cells, oriented with the nucleus closest to the connective tissue, with a tail of cytoplasm entering the surrounding epidermis. Between the dermal papillae are cells arranged in a similar manner above the plexus. Within the snout of $N_{\wedge}$ forsteri, there is a similar branching network of dermal tubules, not ossified, interpreted as enclosing blood vessels by Bemis and Northcutt (1992: Fig. 12) and entering the epidermis of the snout and lips, where they terminate. The entire system fills with latex when the left efferent branchial artery of arch 1 of a small adult lungfish is injected, and must somehow be connected with the blood system. Although the snout and lips of the Australian lungfish are frequently damaged during feeding and burrowing activities, the skin does not bleed (Kemp, 2012a). However, a system to protect the skin is important, even in young hatchlings of $N$. forsteri. Lymphatic vessels are present from early stages, situated in the dermis close to the epidermis and subsequently becoming more elaborate and invading the epidermis. The vessels enclosed within the tubules, the plexus and the dermal papillae tubules are not filled with erythrocytes, but contain lymphocytes. The lymphatic system and its surrounding extracellular matrix in $N$. forsteri is topographically associated with the electroreceptors but not functionally related. Although differing in detail from the structures present in living lungfish, the pore canal system of fossils may be lymphatic as well, and associated with protection of the snout against infection.

Despite loss of mineralisation of the skeleton in general, and of the tubules in particular, in the course of evolutionary change, the system of tubules in the snout found in early fossil sarcopterygians has survived in a few later species (Fox et al., 1995; Cavin 
et al., 2007) and in living lungfish. It is present in all life stages of the Australian lungfish, $N$. forsteri. Preliminary histological analysis of the snout of juvenile South American lungfish, Lepidosiren paradoxa, equivalent to juvenile stages (51-57) of $N$. forsteri, indicates that lymphatic vessels are developing below the epidermis of $L$. paradoxa as well (Kemp unpublished). Presence of lymphatic vessels in tissues of the snout may be protective, as this part of the lungfish is frequently abraded or cut during feeding activities, and the epithelium of the snout has no scales. The trunk and other parts of the head of the lungfish have a heavy cover of imbricating scales (Kemp, 2012b; Pridmore and Barwick, 1993), and the thick epithelium secretes large amounts of mucus. The snout has some cells to secrete mucus, but no scale cover. Moreover, the snout is prone to injury, and other parts of the lungfish, such as the trunk and the ventral surface of the head, are not, at least in a natural environment. Speculation about the evolutionary implications of the tubule system in early sarcopterygians is at this stage unwarranted, except perhaps to mention that it is not found in other groups of fishes and is not present in tetrapods (Chang and Yu, 1997; Schultze, 1994). Possibly, it represents one of the many characters of the sarcopterygian line that is unique to the group.

\section{Acknowledgements}

This research was carried out with permission from the University of Queensland Animal Ethics Committee, approval number CMM/013/03/ARC and the Queensland Fisheries Management Authority, permit number PRM03012K. The work was funded by a grant from the Adelphi Australia Science Foundation,

\section{References}

Barry, J.C., Kemp, A., 2007. High resolution transmission electron microscopy of developing enamel in the Australian lungfish, Neoceratodus forsteri (Osteichthyes: Dipnoi). Tissue Cell 39, 387-398.

Bemis, W.E., Northcutt, G., 1992. Skin and blood vessels of the snout of the Australian lungfish, Neoceratodus forsteri, and their significance for interpreting the cosmine of Devonian lungfishes. Acta Zool. Stockholm 73, 115-139.

Bullock, T.H., Bodznick, D.A., Northcutt, R.G., 1983. The phylogenetic distribution of electroreception, evidence for convergent evolution of a primitive vertebrate sense modality. Brain. Res. Rev. 6, 25-46.

Campbell, K.S.W., Barwick, R.E., 1994. Speonesydrion, an Early Devonian dipnoan with primitive toothplates. Palaeo Ichthyologia 2, 1-48.

Campbell, K.S.W., Barwick, R.E., 2001. Riabolepis and its relationship to the Dipnoi. J Vertebrate Paleontol. 21 (2), 227-241.

Campbell, K.S.W., Wragg, S., in press. Structural details of Early Devonian dipnoans. Aust. J. Zool.

Cavin, L., Suteethorn, V., Buffetaut, E., Tong, H., 2007. A new Thai Mesozoic lungfish (Sarcopterygii, Dipnoi) with an insight into post-Palaeozoic dipnoan evolution. Zool. J. Linn. Soc. Lond. 149, 141-177.

Chang, M.-M., Yu, X., 1997. Reexamination of the relationship of middle Devonian Osteolepids-fossil characters and their interpretations. Am. Mus, Novit. 3189, 20 pp, 4 figures, 1 table.

Cheng, H., 1989. On the tubuli in Devonian lungfish. Alcheringa 13, 153-166.

Collin, S.P., Whitehead, D., 2004. The functional roles of passive electroreception in non-electric fishes. Anim. Biol 54, 1-25.

Denison, R.H., 1968. Early Devonian lungfishes from Wyoming Utah and Idaho. Fieldiana Geol. 17, 353-413.
Fox, R.C., Campbell, K.S.W., Barwick, R.E., 1995. A new osteolepiform fish from the Lower Carboniferous Raymond Formation Drummond Basin, Queensland. Mem. Qld. Mus. 38, 97-221.

Ishiyama, M., Teraki, Y., 1990. The fine structure and formation of hypermineralised petrodentine in the tooth plate of extant lungfish (Lepidosiren paradoxa and Protopterus sp). Arch. Histol. Cytol, 53, 307-321.

Jarvik, E., 1981. Basic Structure and Evolution of Vertebrates, vol. 2. Academic Press, New York.

Joergensen, J.M., 1984. On the morphology of the electroreceptors of the two lungfish Neoceratodus forsteri Krefft and Protopterus annectens Owen. Videnskap Medd. Dan. Naturhist. Foren 145, 77-86.

Joergensen, J.M., 2011. The lateral line system in lungfish: mechanoreceptor neuromasts and electroreceptive ampullary organs. In: Jorgensen, J.M., Joss, J. (Eds.), The Biology of Lungfishes. CRC Press, Enfield, NH pp. 477-492

Kemp, A., 1981. Rearing of embryos and larvae of the Australian lungfish, Neoceratodus forsteri (Krefft) under laboratory conditions. Copeia 1981, 776-784.

Kemp, A., 1982. The embryological development of the Queensland lungfish, Neoceratodus forsteri (Krefft). Mem. Qld. Mus. 20, 553-597.

Kemp, A., 1996. Role of epidermal cilia in development of the Australian lungfish, Neoceratodus forsteri (Osteichthyes: Dipnoi). J. Morphol. 228 203-221.

Kemp, A., 1999. Ontogeny of the skull of the Australian lungfish, Neoceratodus forsteri (Osteichthyes: Dipnoi). J. Zool. 248, 97-137.

Kemp, A., 2001. Petrodentine in derived dipnoan dentitions. J Vert. Paleo. 21, 422-437.

Kemp, A., 2003. The ultrastructure of developing tooth plates in the Australian lung fish, Neoceratodus forsteri. Tissue Cell 35, 401-426.

Kemp, A., 2012a. The World of Lungfish. Andrachne Press, Brisbane, pp. 307pp.

Kemp, A., 2012b. Formation and structure of scales in the Australian lungfish, Neoceratodus forsteri. J. Morphol. 273, 530-540.

Kemp, A., Barry, J.C., 2006. Prismatic dentine in the Australian lungfish ${ }_{\wedge}$ Neoceratodus forsteri (Osteichthyes: Dipnoi). Tissue Cell 38, 127-140.

Kerr, T., 1955. The scales of modern lungfish. Proc. Zool. Soc. Lond. 125, 335-345.

Kramer, B., 1996. Electroreception and communication in Fishes. Prog. Zool. 42, $1-119$.

Lison, L., 1941. Recherches sur la structure et l'histogenèse des dents des Poisson Dipneustes. Arch. Biol 52, 279-320.

Miles, R.S., 1977. Dipnoan (lungfish) skulls and the relationships of the group: a study based on new species from the Devonian of Australia. Zool. J. Linn. Soc. Lond 61, 1-328.

Northcutt, R.G., 1986. Electroreception in non-teleost bony fishes. Chapter 9, pp 257-285. In: Bullock, T.H., Heiligenberg, W. (Eds.), Electroreception. John Wiley and Sons, New York, p. 722.

Pehrson, T., 1949. The ontogeny of the lateral line system in the head of dipnoans Acta Zool. Stockholm 30, 153-182.

Pridmore, P.A., Barwick, R.E., 1993. Post-cranial morphologies of the Late Devonian dipnoans Griphognathus and Chirodipterus and locomotor implications. Mem. Ass. Australas. Palaeontols 15, 161-182.

Roth, A., 1973. Electroreceptors in Brachiopterygii and Dipnoi. Naturwissenschaften $60,106$.

Roth, A., Tscharntke, H., 1976. Ultra-structure of the ampullary electroreceptors in lungfish and Brachiopterygii. Cell Tissue Res 173, 95-108.

Schultze, H.-P., 1987. Dipnoans as Sarcopterygians. J. Morphol. Suppl. 1, 39-74.

Schultze, H.-P., 1994. Comparison of hypotheses on the relationships of Sarcopterygians. Syst. Biol. 43, 155-173.

Schultze, H.-P., Chorn, J., 1997. The Permo-Carboniferous genus Sagenodus and the beginning of modern lungfish. Contrib. Zool. 67, 9-70.

Teller, F.J., 1891. On the skull of a fossil dipnoan C. sturii nov. sp. from the deposits of the Upper Triassic of the North Alps Abhandl. K.K. Geol. Reich. 15 $1-38$

Zhu, M., Wang, W., Yu, X., 2010. Meemannia eos, a basal sarcopterygian fish from the Lower Devonian of China-expanded description and significance. In: Elliott, D.K., Maisey, J.G., Yu, X., Miao, D. (Eds.), Morphology, Phylogeny and Paleobiogeography of Fossil Fishes. Verlag Dr. Friedrich Pfeil, Munchen, Germany, pp. 199-214, 8 figs. 2010.

Zylberberg, L., 1988. Ultrastructural data on the scales of the dipnoan Protopterus annectens (Sarcopterygii: Osteichthyes). J. Zool. Lond. 216, 55-71. 